\title{
Lad EU gøre en forskel Javier Solana
}

\author{
EU-landene bør blive bedre til at beskytte deres \\ fælles interesser og fremme deres fælles værdier, \\ og verden har brug for, at EU træder tydeligere og \\ mere enigt frem og påtager sig et ansvar
}

Vor største vanskelighed med verden i dag er måske, at vi ikke rigtig ved, hvordan vi skal få hold på den. Trods den 11. September er der ikke som under Den Kolde Krig noget entydigt organiserende princip. Der forekommer mange tendenser på samme tid, ofte modsat rettede. Som vi alle ved, havde vi under Den Kolde Krig et system med to blokke, som konkurrerede politisk, økonomisk og ideologisk.

Magtbalancen i dette bipolære system påtvang os international orden og stabilitet. Nogle mennesker giver nogle gange udtryk for 'koldkrigsnostalgi'. Jeg gør det ikke. For jeg kan også huske periodens alvorlige faremomenter. Og den høje pris, som nogle, især i den kommunistiske verden, betalte for stabiliteten $\mathrm{i}$ det overordnede system.

I tiden umiddelbart efter Den Kolde Krig troede vi, at vi havde tre 'zoner': én med stabilitet, én under transition og én under omvæltning. Efter 1989 var der enorm optimisme. Og en tro på, at alle lande efterhånden ville komme ind $\mathrm{i}$ zonen med stabilitet, demokrati og velstand. Den dominerende opfattelse var, at verdenspolitikken ville udvikle sig lineært. Men i dag ved vi, at det ikke passer. Nogle gange synker tilsyneladende stabile lande tilbage i voldelig konflikt. Endnu vigtigere er det, at alle tre zoner overlapper og lever med hinanden på samme tid og nogle gange på samme territorium. På grund af migration, internet og satellit-TV finder vi fjerne og problemfyldte dele af verden midt $\mathrm{i}$ vore byer. Det modsatte gælder også. Man kan finde bittesmå øer af modernitet og stabilitet midt i oceaner af konflikt.

I dag er verden i og for sig ikke mere farlig end før. Men jeg mener, at den er mere kompleks. Det er ikke underligt, hvis mange af vore 
borgere bliver forvirrede. Ved at hjælpe os med at se strukturerne i dette globale puslespil kan forskningen spille en nøglerolle, blandt andet ved at bidrage til at skabe noget, som Europa har svært brug for: et virkeligt strategisk fællesskab. Men vi må blive bedre til at samle vor viden. Over hele Europa analyserer masser af strålende folk vor forvirrende verdens tilstand. Men de arbejder ofte isoleret uden megen koordinering af forskningsprogrammer. På en måde kradser alle $\mathrm{i}$ den samme stump af overfladen. Der er ikke tilstrækkelig gensidig befrugtning.

Hvis vi træder et skridt tilbage, hvad ser vi da? Lad mig gøre tre observationer.

1 I vor globaliserede verden ser vi en integration af markeder og en disintegration af politik.

2 Magt flytter sig, inden for og mellem politiske systemer, og

3 Vi ser fremkomsten af et nyt forhold mellem suverænitet og ansvar.

\section{Ingen 'End of History'}

Ad punkt 1: Globalisering er den dominerende formative kraft i vor verden. Men der er en modsætning mellem integrationen af markederne og den politiske disintegration. Handel, investeringer og finansielle strømme fortsætter med at vokse og operere på globalt niveau. Den dominerende fortælling handler om øget gensidig afhængighed og øko- nomisk integration. Men hvis man betragter verden politisk, ser man stærke centrifugale kræfter: tværs igennem Mellemøsten, i dele af Afrika og andetsteds. Så der er ikke nogen ustoppelig udvikling i retning af en sejrende treenighed af markedsøkonomi, demokrati og menneskerettigheder. Der er ikke nogen 'afslutning på historien'.

Jo, flere og flere lande er frie og demokratiske. Og jo, mange steder står folk fast på deres rettigheder og ønsker regeringer, der kan stilles til ansvar.

Men det er ikke alle, som deler alle vore værdier. Og det er ikke alt, vi brænder for, der vækker universel beundring. Fx betyder globalisering, at ikke-vestlige former for kapitalisme stortrives. Men det gælder også politik og ideologi. Mange beundrer Kinas forbløffende økonomiske vækst. Men ikke bare det. Der er også en anerkendelse, og en fascination, af det forhold, at Kina har opnået både stabilitet og økonomisk fremgang med et politisk system, der er forskelligt fra vort.

Misforstå mig ikke. Jeg er overbevist om, at vi skal fastholde og forsvare vore værdier. I Europa har vi været nødt til at kæmpe længe og hårdt for dem. Men vi må være opmærksomme på historiens og kulturens vægt og prøve at forstå 'den anden'. Og vi må se i øjnene, at den demografiske udvikling gør os til en minoritet i en verden, der fortsætter med at vokse. 


\section{Plads ved bordet}

Det fører mig til min anden observation: Magten flytter sig. Inden for de politiske systemer flyttes magt til markeder, medier og NGO'er. Mellem de politiske systemer flyttes magt fra Vesten til Kina, Indien, Brasilien, Sydafrika, Mexico osv. Det er særdeles velbegrundet at beskæftige sig med, hvordan vi engagerer os med de nye globale spillere.

For at klare de nye udfordringer $\mathrm{i}$ denne nye politiske sammenhæng, må vi samle nye konstellationer af aktører. Det indebærer, at der gøres plads ved den øverste ende af verdenspolitikkens bord: G-8 og FN, men også i de forskellige kontaktgrupper. Men det betyder også, at vi systematisk må involvere ikke-statslige aktører, når politikken planlægges og udføres, for at fremme såvel effektivitet som legitimitet. Det 21. århundredes diplomati vil kræve, at vi kommer ud over det vestligt dominerede, regeringscentrerede verdenssyn.

\section{Pligten til at beskytte}

For det tredje ser jeg, at der er en ny relation på vej mellem suverænitet og ansvar. I stadig stigende grad betragtes suverænitet ikke længere som ubetinget, men som betinget. Kerneidéen bag ansvarlig suverænitet er, at der med statens magt følger ansvar. I forhold til andre stater, men også i forhold til egne borgere.
Stater har ansvar for handlinger, der rækker ud over grænserne og påvirker eller truer andre. Tag klimaændring: vi bliver alle berørt af udledningen af drivhusgasser, lige meget hvor de kommer fra. Eller tag menneskerettigheder: undertrykkelse fører ofte til konflikter, som berører den regionale og globale sikkerhed. Derfor har stater en pligt til at beskytte de essentielle menneskerettigheder. Hvis de krænkes, har andre stater et ansvar for at træde til som beskyttere.

Der er selvfølgelig nogle lande, og for resten ikke kun udviklingslande, der holder fast ved en definition af suverænitet som absolut og ubetinget og ved princippet om ikke-indblanding i andre staters anliggender.

Men ansvaret for at træde til som beskytter er blevet accepteret, i det mindste i princippet, ved FN-topmødet i 2005, og det er værd at notere sig, at konceptet ikke kommer fra Europa, men fra Afrika. Det er også vigtigt, at konceptet kan hjælpe os med at indgå højst tiltrængte pakkeaftaler om fx menneskerettigheder, konflikter og migration, eller terrorisme og udvikling, eller ikke-spredning og nedrustning. I hvert enkelt tilfælde vil vi være nødt til at lave aftaler med et stigende antal aktører baseret på fælles interesser. Det vil altid være svært, men noget lettere, hvis interesserne defineres gennem et prisme, hvor rettigheder og ansvar mødes. 


\section{Tre store udfordringer}

Hvad bør, i denne overordnede sammenhæng, det europæiske svar være? Jeg mener, at EU i de kommende år vil skulle håndtere tre store udfordringer. Den første bliver at få det multilaterale system til at fungere mere effektivt. Den anden består i derudover at optræde på grundlag af egentlige europæiske interesser. Og for det tredje må EU blive bedre til at udbrede til resten af verden det værdisystem, som virkelig kendetegner europæerne. Intet af dette bliver let; men mere end nogensinde tvinger verden os til at handle.

Den første opgave er altså at bidrage til større effektivitet i det multilaterale system. Vi har intet valg; uden retsregler som respekteres, er det jungleloven, der gælder. Hvis der er enighed om reglerne på den internationale scene, er de den bedste garanti for staterne, selv for de stærkeste.

Lad os fx tage Iran, et stort land og et stort folk. Der er ingen grund til at repetere, hvor alvorligt problemet er. Iran fastholder, at dets atomprogram går ud på at installere 20.000 megawatt kernekraftkapacitet til civilt brug. Iran har indgået en aftale om et enkelt kernekraftværk med brændselsforsyning fra Rusland, men har ikke derudover underskrevet en eneste aftale. Og der er ikke taget skridt til at opføre de ca. femten kernekraftværker, som skal til for at man kan leve op til de kernekraftambitioner, man har tilkendegivet.

Det er altså tydeligt, at Iran prøver at berige uran, men lidt ligesom hvis man prøvede at lave sin egen benzin, før man overhovedet havde købt en bil og lært at køre. Der foreligger således et alvorligt tillidsproblem, som forværres på baggrund af tidligere aktiviteter. Kun en multilateral løsning kan redde os ud af denne krise. I dag er det EU, som er bedst i stand til at gå ind i de nødvendige overvejelser og komme med konkrete forslag. Der har i nogen tid været en idé fremme om internationale centre til uranberigelse under multilateral overvågning. Lad os dog forsøge at uddybe den.

\section{Fælles interesser}

Den anden opgave for EU består i at blive bedre til at agere udadtil på grundlag af egentlige europæiske interesser. I menneskelige forhold finder man ikke almeninteressen blot ved at addere alle de individuelle interesser. Det samme gælder for EU. De europæiske interesser er også medlemsstaternes interesser. Men med den lille smule ekstra, som kendetegner vort projekt: ønsket om at leve sammen i fred og sikkerhed, om muligt med evnen til at generere det samme ønske hos vore naboer og andre.

Lad os fx tage EU's forhold til Rusland. Her gælder to realiteter: 
Rusland er vor vigtigste nabo, men også en strategisk partner. Vi kan ikke finde en varig løsning på Kosovo-spørgsmålet eller konflikten i Mellemøsten uden Ruslands medvirken. Logisk må vi handle ved at opstille en række parametre og særinteresser, men også ved at definere mere præcist EU's interesser i forhold til Rusland.

Således forekommer det mig fx åbenbart, at spørgsmålet om energirelationerne ikke kun kan ses i lyset af naboforholdene. Solidaritet indebærer ikke kun, at særinteresser tages i betragtning. Det drejer sig også om den almene interesse. Vi får snart mulighed for at organisere os bedre til at møde disse udfordringer. Det er selve meningen med Reformtraktaten. Omverdenen tvinger os til at agere samlet.

Med traktaten vil vi bedre kunne sætte os igennem, ved at vi samler EU's repræsentation udadtil og ved en mere rationel udnyttelse af de ressourcer, vi har. Men vi må altså ikke glemme, hvor kompleks opgaven er. Vi skal ikke vente noget 'big bang'. Vi skal tværtimod se tiden som en naturlig allieret, fordi det bliver nødvendigt at arbejde med 27 særlige historier og geografier, og fordi konsensus stadig vil være fundamentet for vor fælles handling. Men til sidst vil vi bedre kunne påtage os vort ansvar og forsvare vore interesser. Fælles problemer kræver fælles svar. Det er præcis der, EU's merværdi giver fuld mening.
Og endelig den tredje udfordring for EU: At blive bedre til at udbrede det værdisystem, som virkelig kendetegner europæerne. Al udenrigspolitik må bygge på interesser, men også på værdier. Det gælder i særdeleshed for EU. Vor udenrigspolitik ville ikke være troværdig, hvis vor udenrigspolitik ikke hvilede på vore egne værdier; men det ville ikke være klogt at se bort fra, at vore værdier næppe kan fremmes, uden at det skaber problemer. Vi kan faktisk ikke tage det for givet, at resten af verden, dvs. det meste af menneskeheden, mener at vore værdier også er deres. Nøglen er at stå fast på og udbrede vore værdier i fuld bevidsthed om, at der findes andre.

\section{EU kan gøre en forskel}

Tænk på Den Internationale Straffedomstol og afskaffelsen af dødsstraf. I begge tilfælde er den oprindelige idé i FN europæisk, og den modtages med skepsis eller fjendtlighed. Det tager år at fremme disse sager, og vi forhandler med alle, inklusive initiativernes modstandere. Men til sidst, og uden at give køb på kernen, når vi frem til enighed om teksterne, om internationale regler, og de underskrives af det ene land efter det andet.

Det er disse samme værdier, som styrer vor militære og civile indsats, $\mathrm{i}$ Ituri eller Bosnien i går, i Tchad eller Kosovo i morgen.

Til et globalt spørgsmål hører en 
global løsning; men til et komplekst lokalt problem hører et gennemarbejdet og helst skræddersyet svar. Listen over missioner, der allerede er udsendt, fra Rafah til Kabul og Prishtina ikke mindst, viser opgavens omfang. I vor jargon taler vi om operationer, der er ESDP-autonome (ESDP er den engelske forkortelse for den Europæiske Sikkerheds- og Forsvarspolitik (red.)) eller under Berlin Plus.

Men i realiteten drejer det sig i bund og grund om at forebygge og styre konflikter, gamle eller nye, at bekæmpe smugleri af enhver art (det være sig af mennesker, våben eller narko) og at bekæmpe terrorisme. I overensstemmelse med vore interesser og i respekt for de interesser, som er vore.
Det er ikke let, vil man medgive mig. Ligningen er faktisk kompleks: tjene europæerne og EU selv i en verden i stadig forandring, hvor det ikke-europæiske flertal kræver mere plads og anerkendelse. Men Europa har stadig en enestående mulighed for at gøre en forskel og hjælpe denne nye verden til øget retfærdighed og sikkerhed. Det er jeg overbevist om.

Javier Solana er EU's Høje Representant for Felles Udenrigs- og Sikkerhedspolitik. Denne tale holdt han den 22. november 2007 ved årsmødet i EU's Institut for Sikkerhedsstudier.

Oversat fra engelsk og fransk af Klaus Carsten Pedersen. 